Ghada Y Abdul- Rahman BSc, MSc, PhD (Assist Prof)

Maha M Al-Bazzaz

BDS, MSc (Assist Lect)

Siba M A1-Haliem

BSc, MSc (Assist Lect)

\section{An Evaluation of the Antibacterial} Effects of Rue and Sage Extracts

\author{
Department of Basic Dental Science \\ College of Dentistry, University of Mosul
}

Department of Conservative Dentistry

College of Dentistry, University of Mosul

Department of Basic Dental Science

College of Dentistry, University of Mosul

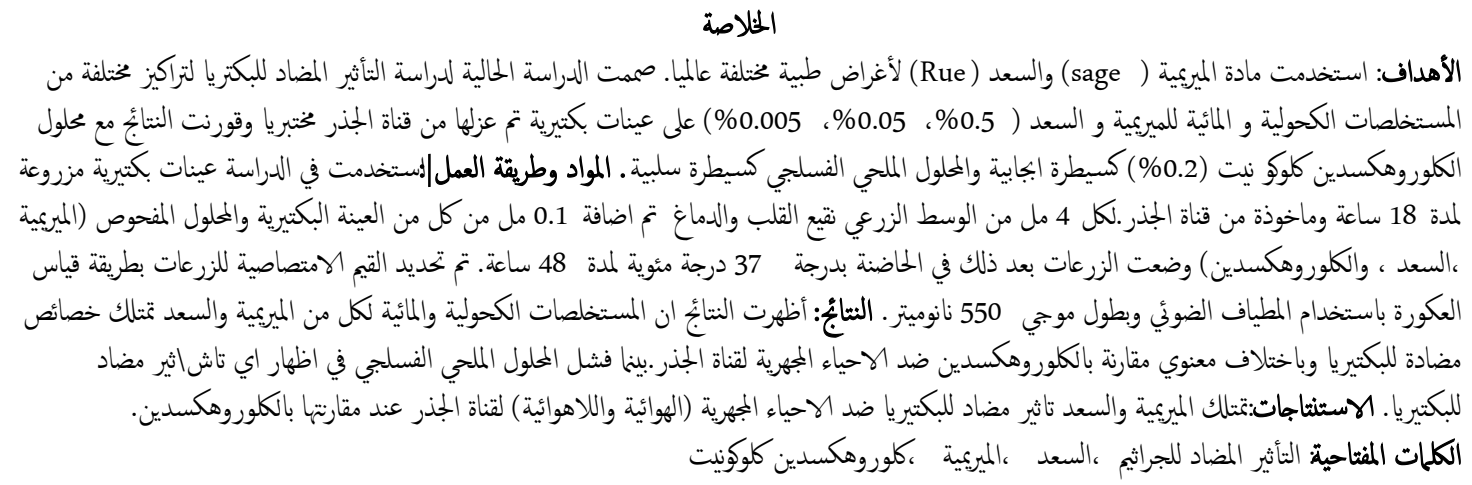

\title{
ABSTRACT
}

Aims: To investigate the antimicrobial effect of different concentrations of ethanolic and aqueous extracts of Sage and Rue $(0.5 \%, 0.05 \%, 0.005 \%)$ on bacterial samples. They were isolated from root canal system in vitro, and the results were compared with that of chlorhexidine gluconate $(0.2 \%)$ as a positive control and normal saline as a negative control. Materials and Methods: Eighteen hours cultured bacterial samples of the root canal were used. To each $4 \mathrm{ml}$ of Brain Heart Infusion Broth (BHI), $0.1 \mathrm{ml}$ of both bacterial sample and the examined solution Sage, Rue and chlorhexidine were added. Cultures were incubated at $37{ }^{\circ} \mathrm{C}$ for 48 hours. The absorbance values of the cultures were determined by the turbidity method using spectrophotometer at $(550 \mathrm{~nm})$. Results: The results showed that both ethanolic and aqueous extracts of Sage and Rue have antibacterial effects in all concentrations with a significant variance compared with chlorhexidine against root canal microorganisms, while normal saline failed to show any antimicrobial activity. The results also showed that the ethanolic extracts of both plants have a higher antibacterial activity than the aqueous extracts. Conclusions: Rue and Sage demonstrated antibacterial effects on the root canal microorganisms (both aerobic and anaerobic) when compared with chlorhexidine.

Key words: Antibacterial effect, Rue, Sage, Chlorhexidine gluconate.

Abdul- Rahman GY, Al-Bazzaz MM, Al-Haliem SM. An Evaluation of the Antibacterial Effects of Rue and Sage Extracts. Al-Rafidain Dent J. 2010; 10(1): 55-61.

Received: 19/5/2008 Sent to Referees: 19/5/2008

Accepted for Publication: 4/11/2008

\section{INTRODUCTION}

Due to the indiscriminate use of antimicrobial drugs, microorganisms have developed resistance to several antibiotics and created immense clinical problems in the treatment of infectious diseases ${ }^{(1)}$.
There is a need to develop alternative antimicrobial drugs for the treatment of infectious diseases. One approach is to screen new inexpensive and effective drugs from other sources including plants for the possible antimicrobial properties ${ }^{(2)}$. 
Herbal products are well-known for their reputed medicinal properties, however, most of them are empirically used $^{(3)}$.

Ruta graveolens (Rue): Several plants of the Rutaceae family are used in the traditional medicine worldwide. The most common medicinal plant of this family is Ruta graveolens, known as Rue and native to Europe. This plant is in Medicinal use for various clinical conditions from very ancient time but rationality of its use is still controversial. In homeopathy, Rue is an important remedy for deep acting pain and Rheumatism besides being used for eyestrain - induced headache ${ }^{(4)}$.

It has also been used as a remedy for gastric disorders, stiff neck, dizziness, headache and soon ${ }^{(5)}$.

Rue contains different active compounds, out of them rutin, a flavonoid, coumarins which is responsible for the antimicrobial activity of Rue ${ }^{(6)}$.

Salvia officinalis (Sage): is a large and polymorphous genus of the family Lamiaceae, comprising about 900 species with almost cosmopolitan dissemination. A special position among them has the herbal species of Salvia officinalis $^{(1)}$.

The prevailing components in the plant extract obtained by ultrasound extraction were alpha - thujone $(48.4 \%)$ and camphor $(14.2 \%)$, in the methylene chloride extract were alpha - thujone (15.7 $59.3 \%), 1,8$-cineole $(10.9-43.1 \%)$ and beta-thujone $(4.9-25.8 \%)$. Some components of the plant extract and the essential oils of Salvia officinalis have antimicrobial activity. Linalyl acetate and terpineol have the greatest power of bacterial inhibition $^{(7)}$.

Salvin from acetone extract of the dried flowers is effective against Staphylococcus aureas ${ }^{(8)}$. The hart Sage has along history of use in food and medicine and was used topically for the treatment of wounds, sprains and muscle injuries and as a gargle for sore throat, hoarseness and cough $^{(2)}$.

The aim of this study to investigate the antimicrobial effect of different concentrations of ethanolic and aqueous extract of Sage and Rue $(0.5 \%, 0.05 \%, 0.005 \%)$ on bacterial samples isolated from root canal in vitro and compare the results with chlorhexidine $(0.2 \%)$ as a positive control and normal saline as a negative control.

\section{MATERIALS AND METHODS}

A. Preparation of Plants Extract:

1. Aqueous extract of Sage and Rue:

Two hundred and fifty grams of the plants were grounded to powder using commercially available food blender (S.S/ GLASSCO/ India) and then the powder was mixed with 1 liter of distilled water and left at $4^{\circ} \mathrm{C}$ for 24 hours. Then the resultant mixture were filtered through two layers of gauze and again passed through No. 1 filter paper to get rid of the gross ruminants of the mixture ${ }^{(9)}$. A turbid thick solution of $100 \%$ concentration was obtained. The dilutions were made with distilled water according to the following equation advocated by Summerlin $(1981)^{(10)}$ (law of dilution); volume(1) x concentration(1)=volume $(2) \mathrm{x} \quad$ concentration(2). Three dilutions were prepared $(0.5 \%$, $0.05 \%$ and $0.005 \%$ ).

2. Ethanolic extract of Sage and Rue:

Two hundred fifty grams of the plants were grounded to powder using commercially available food blender (S.S/GLASSCO/India) and then 1 liter of 95\% ethanol was added in an ice bath, left for 7 days inside well capped sterile flask at room temperature, then the mixture was filtered using many layers of gauze, then passed through No. 1 filter paper and then resultant mixture was kept in the incubator to get rid - off the ethanol, and the dilutions were done using Dimethyl sulfoxide (DMSO), because this solution has no effect on the bacteria and also help to dissolve the active ingredients of the plants. Three dilutions were prepared $(0.5,0.05$, $0.005)^{(9)}$.

\section{B. Antimicrobial Study:}

The antimicrobial activities of ethanolic and aqueous extracts of Sage and Rue against 18 hours cultured bacterial samples of root canal were measured. To each $4 \mathrm{ml}$ of Brain Heart Infusion broth (BHI) (oxoid), $0.1 \mathrm{ml}$ of the bacterial sample and $0.1 \mathrm{ml}$ of the examined solution (Sage, Rue, CHX) were added.

Cultures were incubated directly in an 
incubator (Fisher Scientific / Russia) at $37^{\circ} \mathrm{C}$ for 48 hours at least three replicates of each treatment were incubated as well as the normal or untreated microorganisms culture. For the anaerobic growth of microorganism, to each $4 \mathrm{ml}$ of thioglycollate broth (Oxoid LTD, Basigstoke, Hants / England), $0.1 \mathrm{ml}$ of the bacterial sample and $0.1 \mathrm{ml}$ of the examined solution (Sage, Rue, chlorhexidine) were added. Cultures were incubated at $37^{\circ} \mathrm{C}$ for 48 hours inside an anaerobic jar.

In this study there were positive control, negative control and treatment vials. A negative control vial represents a turbidity which is caused by the examined solution, but the positive control vial represents a turbidity which is caused by bacterial growth alone. In order to determine the antibacterial effect of each examined solution, the turbidity of the examined solution itself must be excluded ${ }^{(11)}$.

The turbidity or absorbance of the cultures were determined by the turbidity method, using spectrophotometer at (550) $\operatorname{rim}^{(12)}$.

The data (absorbance values) were tested for their significance by Duncan multiple range analysis test at $p \leq 0.05$ probability.

\section{RESULTS}

The analysis of variance at level $p \leq$ 0.05 was performed. The mean of the absorbance values in $(\mathrm{nm})$ of the replicates were measured and compared with the control group by Duncan's New Multiple Range test. This was shown in Tables (18).

The results revealed that all concentrations of ethanolic extract of Sage and Ruta $(0.5,0.05,0.005), 0.2 \%$ chlorhexidine had antimicrobial effect against anaerobic microorganisms significantly different from the control group, however, normal saline failed to show any significant effect.

Table (1) shows that the ethanolic extract of Sage (SEE) at $0.05 \%$ concentration had the highest antibacterial activity on anaerobic growth of root canal bacteria which is significantly not different from SEE in concentrations of $(0.005 \%, 0.5 \%)$ and $0.2 \%$ chlorhexidine. This Table also showed that SEE at concentration of $0.05 \%$ had higher antibacterial activity than $0.5 \%$ but significantly not different. Also SEE at $(0.05 \%, 0.5 \%)$ concentrations had antimicrobial effect higher than that of $0.2 \%$ chlorhexidine but significantly not different.

Table (1): The analysis of absorbance values of different treatment against anaerobic microorganisms from root canal compared with different concentration of ethanolic extract of Sage.

\begin{tabular}{cccccc}
\hline Materials & No. & Mean & $\begin{array}{c}\text { Standard } \\
\text { deviation }\end{array}$ & $\begin{array}{c}\text { Standard } \\
\text { error }\end{array}$ & $\begin{array}{c}\text { Duncan's } \\
\text { group* }\end{array}$ \\
\hline SEE 0.5\% & 4 & 0.057 & 0.023 & 0.011 & $\mathrm{~A}$ \\
SEE 0.05\% & 4 & 0.027 & 0.012 & 0.006 & $\mathrm{~A}$ \\
SEE 0.005\% & 4 & 0.031 & 0.017 & 0.008 & $\mathrm{~A}$ \\
Chlorhexidine & 4 & 0.060 & 0.001 & 0.000 & $\mathrm{~A}$ \\
Normal saline & 4 & 0.923 & 0.023 & 0.011 & $\mathrm{~B}$ \\
\hline
\end{tabular}

SEE: Ethanolic extract of Sage. *Different letters mean significant difference at $p \leq 0.05$.

Table (2) shows that SEE at $0.05 \%$ concentration had the higher antimicrobial activity on aerobic growth of root canal bacteria which is significantly not different from $0.2 \%$ chlorhexidine and significantly different from SEE at $(0.005 \%, 0.5 \%)$ concentrations. $0.2 \%$ chlorhexidine had antimicrobial effect higher than that of SEE at $(0.005 \%, 0.5 \%)$ which is significantly different. SEE at $0.005 \%$ concentration had antimicrobial effect nearly similar to that of $0.5 \%$. 
Table (2): The analysis of absorbance values of different treatment against aerobic microorganisms from root canal compared with different concentration of ethanolic extract of Sage.

\begin{tabular}{cccccc}
\hline Materials & No. & Mean & $\begin{array}{c}\text { Standard } \\
\text { deviation }\end{array}$ & $\begin{array}{c}\text { Standard } \\
\text { error }\end{array}$ & $\begin{array}{c}\text { Duncan's } \\
\text { group* }\end{array}$ \\
\hline SEE 0.5\% & 4 & 0.190 & 0.028 & 0.014 & $\mathrm{C}$ \\
SEE 0.05\% & 4 & 0.105 & 0.044 & 0.022 & $\mathrm{~B}$ \\
SEE 0.005\% & 4 & 0.037 & 0.032 & 0.016 & $\mathrm{~A}$ \\
Chlorhexidine & 4 & 0.081 & 0.004 & 0.002 & $\mathrm{AB}$ \\
Normal saline & 4 & 0.890 & 0.061 & 0.030 & $\mathrm{D}$ \\
\hline
\end{tabular}

SEE: Ethanolic extract of Sage. ${ }^{*}$ Different letters mean significant difference at $p \leq 0.05$.

Table (3) shows that $0.2 \%$ chlorhexidine had the higher antimicrobial activity on anaerobic growth of root canal bacteria which is significantly different from the aqueous extract of Sage (SAE) at concentrations of $(0.5 \%, 0.05 \%, 0.005 \%)$. SAE at $0.5 \%$ had nearly similar antimicrobial effect to that of $0.05 \%$ which is significantly different from SAE at $0.005 \%$ concentra- tion. Table (4) shows that $0.2 \%$ chlorhexidine had the best antibacterial activity on aerobic growth of root canal bacteria which is significantly different from SAE at $(0.5 \%, 0.05 \%, 0.005 \%)$ concentrations. SAE in all concentrations showed nearly similar activity on aerobic bacteria of the root canal.

Table (3): The analysis of absorbance values of different treatment against anaerobic microorganisms from root canal compared with different concentration of aqueous extract of Sage.

\begin{tabular}{cccccc}
\hline Materials & No. & Mean & $\begin{array}{c}\text { Standard } \\
\text { deviation }\end{array}$ & $\begin{array}{c}\text { Standard } \\
\text { error }\end{array}$ & $\begin{array}{c}\text { Duncan's } \\
\text { group* }\end{array}$ \\
\hline SAE 0.5\% & 4 & 0.262 & 0.058 & 0.029 & $\mathrm{~B}$ \\
SAE 0.05\% & 4 & 0.283 & 0.061 & 0.030 & $\mathrm{~B}$ \\
SAE 0.005\% & 4 & 0.388 & 0.028 & 0.014 & $\mathrm{C}$ \\
Chlorhexidine & 4 & 0.026 & 0.005 & 0.002 & $\mathrm{~A}$ \\
Normal saline & 4 & 0.862 & 0.046 & 0.023 & $\mathrm{D}$ \\
\hline
\end{tabular}

SAE: Aqueous extract of Sage.*Different letters mean significant difference at $p \leq 0.05$.

Table (4): The analysis of absorbance values of different treatment against aerobic microorganisms from root canal compared with different concentration of aqueous extract of Sage.

\begin{tabular}{cccccc}
\hline Materials & No. & Mean & $\begin{array}{c}\text { Standard } \\
\text { deviation }\end{array}$ & $\begin{array}{c}\text { Standard } \\
\text { error }\end{array}$ & $\begin{array}{c}\text { Duncan's } \\
\text { group* }\end{array}$ \\
\hline SAE 0.5\% & 4 & 0.588 & 0.074 & 0.037 & $\mathrm{~B}$ \\
SAE 0.05\% & 4 & 0.553 & 0.056 & 0.028 & $\mathrm{~B}$ \\
SAE 0.005\% & 4 & 0.560 & 0.074 & 0.037 & $\mathrm{~B}$ \\
Chlorhexidine & 4 & 0.058 & 0.004 & 0.002 & $\mathrm{~A}$ \\
Normal saline & 4 & 0.905 & 0.028 & 0.014 & $\mathrm{C}$ \\
\hline
\end{tabular}

SAE: aqueous extract of Sage. *Different letters mean significant difference at $p<0.05$.

Table (5) shows that $0.2 \%$ chlorhexidine demonstrated the best antimicrobial activity an anaerobic growth of root canal bacteria which is significantly not different from the aqueous extract of Ruta (RAE) at $0.5 \%$ concentration and significantly different from RAE at $0.5 \%$ and $0.005 \%$ concentrations. Regarding RAE the best anti- microbial activity was shown at concentration of $0.5 \%$, which is significantly different from RAE at concentrations at $(0.05 \%$, $0.005 \%)$. Also the results showed that RAE at $(0.05 \%)$ had the higher antimicrobial effect than $0.005 \%$ but significantly not different. 
Table (5): The analysis of absorbance values of different treatment against anaerobic microorganisms from root canal compared with different concentration of aqueous extract of Rue.

\begin{tabular}{cccccc}
\hline Materials & No. & Mean & $\begin{array}{c}\text { Standard } \\
\text { deviation }\end{array}$ & $\begin{array}{c}\text { Standard } \\
\text { error }\end{array}$ & $\begin{array}{c}\text { Duncan's } \\
\text { group* }\end{array}$ \\
\hline RAE 0.5\% & 4 & 0.045 & 0.014 & 0.007 & $\mathrm{~A}$ \\
RAE 0.05\% & 4 & 0.131 & 0.029 & 0.014 & $\mathrm{~B}$ \\
RAE 0.005\% & 4 & 0.180 & 0.009 & 0.004 & $\mathrm{C}$ \\
Chlorhexidine & 4 & 0.021 & 0.004 & 0.002 & $\mathrm{~A}$ \\
Normal saline & 4 & 0.926 & 0.022 & 0.011 & $\mathrm{D}$ \\
\hline
\end{tabular}

RAE: Aqueous extract of Rue. *Different letters mean significant difference at $p<0.05$.

Table (6) shows that $0.5 \%$ had the best antimicrobial activity on aerobic bacteria which is significantly not different from RAE at concentrations of $0.05 \%$ and $0.005 \%$. The difference was not different between RAE at $0.05 \%$ and $0.005 \%$ concentration. $0.2 \%$ chlorhexidine showed the highest antimicrobial activity on aerobic bacteria which is significantly different from RAE in all concentrations. Table (7) shows that $0.2 \%$ chlorhexidine had the highest antimicrobial activity on anaerobic growth of bacteria which is significantly not different from ethanolic extract of $\mathrm{Ru}-$ ta (REE) in all concentrations. REE at $0.005 \%$ showed the best antimicrobial activity on anaerobic bacteria which is significantly not different from REE at $0.0 \%$ and $0.5 \%$ concentrations. The difference was not significant between $0.05 \%$ and $0.5 \%$ concentration.

Table (6): The analysis of absorbance values of different treatment against aerobic microorganisms from root canal compared with different concentration of aqueous extract of Rue.

\begin{tabular}{cccccc}
\hline Materials & No. & Mean & $\begin{array}{c}\text { Standard } \\
\text { deviation }\end{array}$ & $\begin{array}{c}\text { Standard } \\
\text { error }\end{array}$ & $\begin{array}{c}\text { Duncan's } \\
\text { group* }\end{array}$ \\
\hline RAE 0.5\% & 4 & 0.247 & 0.145 & 0.072 & $\mathrm{~B}$ \\
RAE 0.05\% & 4 & 0.256 & 0.133 & 0.066 & $\mathrm{~B}$ \\
RAE 0.005\% & 4 & 0.373 & 0.132 & 0.061 & $\mathrm{BC}$ \\
Chlorhexidine & 4 & 0.058 & 0.004 & 0.002 & $\mathrm{~A}$ \\
Normal saline & 4 & 0.911 & 0.024 & 0.012 & $\mathrm{D}$ \\
\hline
\end{tabular}

RAE: aqueous extract of Rue. *Different letters mean significant difference at $p<0.05$.

Table (7): The analysis of absorbance values of different treatment against anaerobic microorganisms from root canal compared with different concentration of ethanolic extract of Rue.

\begin{tabular}{cccccc}
\hline Materials & No. & Mean & $\begin{array}{c}\text { Standard } \\
\text { deviation }\end{array}$ & $\begin{array}{c}\text { Standard } \\
\text { error }\end{array}$ & $\begin{array}{c}\text { Duncan's } \\
\text { group* }\end{array}$ \\
\hline REE 0.5\% & 4 & 0.088 & 0.065 & 0.032 & $\mathrm{~A}$ \\
REE 0.05\% & 4 & 0.088 & 0.065 & 0.032 & $\mathrm{~A}$ \\
REE 0.005\% & 4 & 0.060 & 0.041 & 0.020 & $\mathrm{~A}$ \\
Chlorhexidine & 4 & 0.025 & 0.004 & 0.002 & $\mathrm{~A}$ \\
Normal saline & 4 & 0.917 & 0.034 & 0.017 & $\mathrm{~B}$ \\
\hline
\end{tabular}

REE: Ethanolic extract of Rue. *Different letters mean significant difference at $p<0.05$.

Table (8) shows that REE in all concentrations had higher antimicrobial effect on aerobic growth of bacteria than that of $0.2 \%$ chlorhexidine but significantly not different. $0.05 \%$ concentration showed the best antimicrobial effect but significantly not different from the other two concentrations $(0.005 \%, 0.05 \%)$. EE at $0.5 \%$ concentration had a nearly similar antimicrobial effect to that on $0.05 \%$. 
Table (8): The analysis of absorbance values of different treatment against aerobic microorganisms from root canal compared with different concentration of ethanolic extract of Rue.

\begin{tabular}{cccccc}
\hline Materials & No. & Mean & $\begin{array}{c}\text { Standard } \\
\text { deviation }\end{array}$ & $\begin{array}{c}\text { Standard } \\
\text { error }\end{array}$ & $\begin{array}{c}\text { Duncan's } \\
\text { group* }\end{array}$ \\
\hline REE 0.5\% & 4 & 0.036 & 0.023 & 0.011 & $\mathrm{~A}$ \\
REE 0.05\% & 4 & 0.025 & 0.007 & 0.003 & $\mathrm{~A}$ \\
REE 0.005\% & 4 & 0.030 & 0.015 & 0.007 & $\mathrm{~A}$ \\
Chlorhexidine & 4 & 0.041 & 0.019 & 0.009 & $\mathrm{~A}$ \\
Normal saline & 4 & 0.905 & 0.017 & 0.008 & $\mathrm{~B}$ \\
\hline
\end{tabular}

REE: Ethanolic extract of Rue. *Different letters mean significant difference at $p<0.05$.

\section{DISCUSSION}

Many researchers reported the antibacterial activity of medicinal plants but many results were slightly different from this study. Variation between the results reported by previous researchers and our study could be due to differences in the plants physiological state of development, diurnal and seasonal variation, environmental condition, part of the plants, extraction procedure, concentration of the crude extracts and strains of microorganisms.

The results suggest the presence of good antimicrobial activity of the ethanolic, extract of Sage and Ruta against anaerobic microorganisms, that is significantly higher than that of the aqueous extract. The supposed resistance of the aerobic microorganisms may be related to several factors, such as, cell wall structure, metabolic product secreted and resistance to antimicrobial agents ${ }^{(13)}$. For this study, each concentration of the plant extract was tested against bacterial samples of the root canal. It was evident that all concentrations have antimicrobial activity significantly not different from that of chlorhexidine gluconate.

The results of the examined antimicrobial activities of Sage extract showed that the aqueous extract have less antimicrobial effect than the ethanolic extract. It was clearly stated that plants contained microbial inhibitors (i.e., flavonoids) soluble in aqueous ethanol and flavonoid aglycones were more active than their glycosidic forms naturally present in plants $^{(14)}$. This may partly explain the broad inhibitory activity of ethanolic extract of the plants compared with that of crude extracts.

\section{CONCLUSIONS}

Rue and Sage demonstrated antibacterial effects on root canal microorganisms (both aerobic and anaerobic) when compared with chlorhexidine.

\section{REFERENCES}

1. Davis J. Inactivation of antibiotics and the dissemination of resistance genes. Science. 1994; 264: 375-382.

2. Catherine W, Githinji, Kokwaro JO. Ethnomedicinal study of major species in the family Labiatae from Kenya. J Ethnopharmacol. 1993; 39: 197-203.

3. Dhikav V, Singh S, Anand KS. Newer non-steroidal anti-inflammatory drugs-a review of their therapeutic potential and adverse drug reactions. $J$ Indian Academy Chem Medicin. 2002; 3: 332-338.

4. Miguel ES. Rue (Ruta L, Rutaceae) in traditional span: frequency and distribution of its medicinal and symbolic applications. Economic Botany. 2003; 57: 231244.

5. Conway GA, Slocumb JC. Plants used as a bortifacients and emmenagogues by Spanish New Mexicans. J Ethnopharmacology. 1979; 1: 241-261.

6. Lawrence RN. Rediscovering natural product biodiversity. Drug Discovery Today. 1999; 4: 449-451.

7. Adams RP. Identification of essential oil components by gas chromatography / quadruple mass spectroscopy. Allured publ. Corp. Carol stream, Illinois. 2001.

8. Amin A, Hamza AA. Salvia officinalis extract in the treatment of patient with mild to moderate Alzxeheimer's disease. $J$ Clin Pharm Then. 2005; 28: 53-59.

9. Khodair AI, Hammouda FA, Abdel-Azim $\mathrm{H}$. Phytochemical investigation of thymus de cassatus L. Qutar Univers Sci J. 1993; 
3(12): 211-213.

10.Summerlin S. Chemistry of the life sciences dilution problems. $1^{\text {st }}$ ed. RHI Co, New York, USA. 1981. P: 158.

11.Abdul Rahman GY, Khalaf SH. The use of some medicinal plants in dental caries prevention. Al-Rafidian J Sci. 2002; 13: 1.

12. Abdul Rahman GY. A study of cariogenic bacteria isolated in Mosul City. PhD Thesis. College of Sciences. University of
Mosul. 2001.

13. Sriskandam S, Cohen J. Gram-positive sepsis mechanisms and difference from gram-negative species. Dent Clin North Am. 1999; 13: 397-412.

14. Rauha J, Remes S, Heinonen M. Antimicrobial effect of Finnish plant extracts containing flavonoids and the phenolic compounds. Int J Food microbial. 2000; 56: $3-12$ 